\title{
Development of XMRV producing B Cell lines from lymphomas from patients with Chronic Fatigue Syndrome
}

\author{
Francis Ruscetti ${ }^{1 *}$, Vincent C Lombardi ${ }^{2}$, Michael Snyderman ${ }^{3}$, Dan Bertolette ${ }^{4}$, Kathryn S Jones ${ }^{1}$, Judy A Mikovits ${ }^{1}$ \\ From 15th International Conference on Human Retroviruses: HTLV and Related Viruses \\ Leuven and Gembloux, Belgium. 5-8 June 2011
}

Previous studies have shown that CFS patients have an increased incidence of lympho-proliferative malignancy compared to the normal population [1]. While the incidence rate of non-Hodgkin's lymphoma in the United States is $0.02 \%$, nearly $5 \%$ of the CFS patients developed the disease. Additionally, development of cancer coincides with an outgrowth of gamma delta $\mathrm{T}$ cells with specific clonal $\mathrm{T}$-cell receptor gamma rearrangements. We hypothesized that infection with XMRV and/or other viruses can trigger a dysregulated immune response which favors the development of B-cell lymphoma.

In a study of 300 CFS patients, 13 developed lymphoproliferative disorders. Of those tested, 11/11 were positive for XMRV and 9/9 positive for clonal TCR gamma rearrangements. Spontaneous development of four B cells lines occurred during culture of cells from CFS patients. Three developed from $B$ cells isolated from the peripheral blood (two of whom had B cell lymphoma) and one from a bone marrow biopsy. For all four lines, the $\mathrm{B}$ cells have a mature $\mathrm{CD} 20+, \mathrm{CD} 23+$ phenotype and produce infectious XMRV at a titer of $>10^{6}$ infectious units/ml. Virus production occurred despite extensive hypermutation of the proviruses in these cells by APOBEC3G.. Therefore XMRV infection may accelerate the development of $\mathrm{B}$ cell malignancies by either indirect chronic stimulation of the immune system and/or by direct infection of the B-cell lineage. Since viral load in peripheral blood is low, these data suggest that B cells in tissues such as spleen and lymph nodes could be an in vivo reservoir for XMRV.

* Correspondence: ruscettf@mail.nih.gov

'Center for Cancer Research NCI-Frederick, Frederick, Maryland, 21702, USA

Full list of author information is available at the end of the article

\section{Author details}

${ }^{1}$ Center for Cancer Research NCI-Frederick, Frederick, Maryland, 21702, USA. ${ }^{2}$ Whittemore Peterson Institute, University of Nevada, Reno, Nevada, 89557, USA. ${ }^{3}$ Department of Medicine, State University of New York at Buffalo, Buffalo, New York, USA. ${ }^{4}$ Basic Research Program, SAIC-Frederick, Inc., NCIFrederick, Frederick, Maryland, 21702, USA.

Published: 6 June 2011

Reference

1. Fears TR, Cummings P, Hoover RN: Cancer and a fatiguing illness in Northern Nevada: a causal hypothesis. Ann Epidemiol 1998, 8:245-249.

doi:10.1186/1742-4690-8-S1-A230

Cite this article as: Ruscetti et al:: Development of XMRV producing B Cell lines from lymphomas from patients with Chronic Fatigue Syndrome. Retrovirology 2011 8(Suppl 1):A230.

Submit your next manuscript to BioMed Central and take full advantage of:

- Convenient online submission

- Thorough peer review

- No space constraints or color figure charges

- Immediate publication on acceptance

- Inclusion in PubMed, CAS, Scopus and Google Scholar

- Research which is freely available for redistribution

Submit your manuscript at www.biomedcentral.com/submit 